Dicle Tıp Dergisi / Dicle MedJ (2019) 46 (3) : 525 - 534

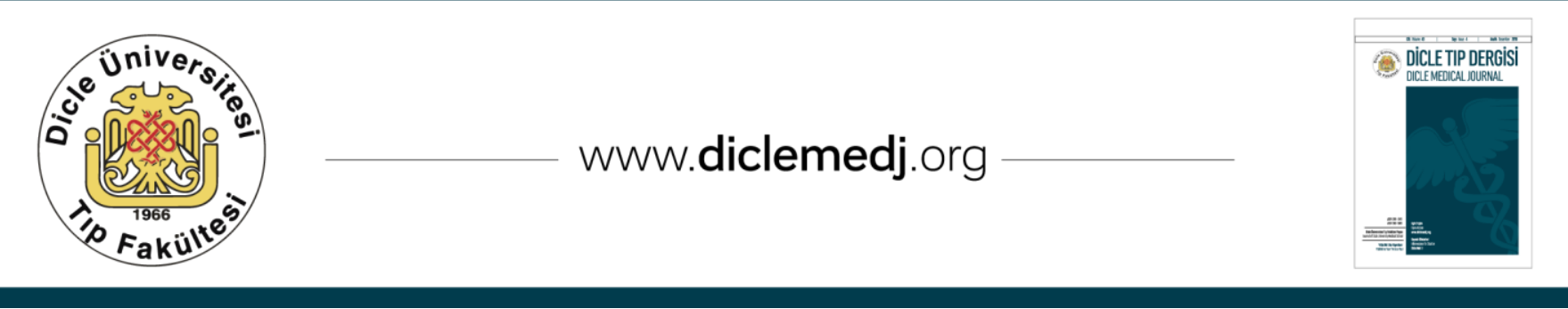

Özgün Araștırma / Original Article

\title{
Over, Böbrek ve Beyinde İskemi / Reperfüzyon Sonrası Redoks Dengesi ve Tribulus Terrestris L.'nin Etkileri
}

\author{
Enver Ahmet Demir ${ }^{1}$ \\ 1 Hatay Mustafa Kemal Üniversitesi, Tayfur Ata Sökmen Tıp Fakültesi, Fizyoloji Anabilim Dall, Hatay, Türkiye ORCID: 0000-0002-2620-6192
}

Geliş: 15.05.2019; Revizyon: 28.05.2019; Kabul Tarihi: 21.06.2019

\section{Öz}

Amaç: Oksidatif stres prooksidan ve antioksidan sistemler arasında oksidasyon lehine bir dengesizlik olarak tanımlanır ve iskemi / reperfüzyon hasarı gibi çeşitli patolojilerden sorumlu tutulmaktadır. Eksojen antioksidanlar redoks dengesinin geri kazanılmasında faydalıdırlar. Tribulusterrestris L. (demir dikeni) güçlü antioksidan etki sergileyen flavonoidler ve saponinler açısından zengin bir tıbbi bitkidir. Bu çalışma over, böbrek ve beyinde reperfüzyon hasarında Tribulus ekstresinin redoks dengesi üzerine etkilerini araştırmayı hedeflemiştir.

Yöntemler: Dişi Wistar albino sıçanlaraTribulus veya fizyolojik salin uygulandı ve hayvanlar 60 dakika süreli over, böbrek ya da beyin iskemisini takip eden 60 dakika süreli reperfüzyona maruz bırakıldılar. Bahsedilen dokularda total antioksidan durum (TOS), total oksidan durum (TAS) ve oksidatif stres indeksi (OSI) belirlendi.

Bulgular: Tribulus'un over, böbrek ve beyinde yalnızca reperfüzyon hasarı oluşturulan hayvanlara kıyasla TOS'u düşürdüğü bulundu (sırasıyla, p<0.001, p=0.004 ve p=0.035). Aynı zamanda Tribulus uygulamasıyla her üç dokuda yalnızca reperfüzyon hasarı oluşturulan hayvanlara kıyasla redoks dengesinin önemli bir göstergesi olan OSI'de azalma sağlandı (over: $\mathrm{p}<0.001$, böbrek: $\mathrm{p}=0.007$ ve beyin: $\mathrm{p}=0.002$ ).

Sonuç: Bu bulgular Tribulus'un reperfüzyon hasarının yüksek oksidatif ortamında dahi güçlü bir antioksidan etki sergilediğini ortaya koymaktadır. Oksidatif stresin reperfüzyon hasarının yıkıcı sürecine iştiraki düșünüldüğünde Tribulus'un stresi sınırlayıcı etkisi, redoks dengesinin korunmasına katkı sunmak marifetiyle reperfüzyon hasarına karşı faydalı olabileceğini göstermektedir.

Anahtar Kelimeler: Tribulus, demir dikeni, oksidatif stres, iskemi, reperfüzyon.

DOI: $10.5798 /$ dicletip.620570

Yazışma Adresi / Correspondence: Enver Ahmet Demir, Hatay Mustafa Kemal Üniversitesi, Tayfur Ata Sökmen Tıp Fakültesi, Fizyoloji Anabilim Dalı, Hatay, Türkiye 31040 e-mail: demirea@live.com 


\title{
Effects of Tribulus Terrestris L. and Post-Ischemia/Reperfusion Redox Balance in Ovaries, Kidneys, and Brain
}

\begin{abstract}
Objective: Oxidative stress is defined as the imbalance in pro-oxidative and anti-oxidative systems in favor of oxidation, and it is held responsible for numerous pathologies including ischemia/reperfusion injury. Exogenous antioxidants are of benefit to the restoration of the redox balance. Tribulusterrestris L. (devil's weed) is a medicinal herb, rich in flavonoids and saponins that exert strong anti-oxidant actions. The present study was aimed to investigate the effects of Tribulus extract on the redox balance in ovarian, renal and cerebral reperfusion injury.

Method: Female Wistar albino rats were either received Tribulus or physiological saline and undergone to ovarian, renal or cerebral ischemia for 60 minutes followed by a 60-minute-long reperfusion. Total anti-oxidant status (TAS), total oxidant status (TOS) and oxidative stress index (OSI) were estimated in the mentioned tissues.

Results: Tribulus was found to reduce TOS in ovaries, kidneys and brain as compared with the animals in which only reperfusion injury was generated (respectively, $\mathrm{p}<0.001, \mathrm{p}=0.004$ and $\mathrm{p}=0.035$ ). Meanwhile, a decrease in 0 SI, a pivotal indicator of the redox balance, was acquired with Tribulus administration in all three tissues compared with the animals in which only reperfusion injury was generated (ovary: $p<0.001$, kidney: $p=0.007$ and brain: $p=0.002$ ).

Conclusion: These findings demonstrate that Tribulus possesses a strong anti-oxidant effect even in highly oxidative environment of reperfusion injury. Since oxidative stress participates in the destructive process in reperfusion injury, the stress-limiting feature of Tribulus can offer a use against the reperfusion injury through supporting maintenance of the redox balance.
\end{abstract}

Keywords: Tribulus, devil's weed, oxidative stress, ischemia, reperfusion.

\section{GíRiş}

Oksidatif stres, biyolojik aktivitenin yan ürünleri olan reaktif oksijen ve nitrojen türevlerinin antioksidan savunmaya üstün hale gelmesi neticesinde redoks dengesinin prooksidanlar lehine değişmesidir ${ }^{1}$. Prooksidanlar fizyolojik sınırları içerisinde kaldıkları sürece hücrenin yaşamsal fonksiyonlarını sürdürmesinde görev alırlarken aşırı üretilmeleri halinde membran lipitleri, proteinler ve genetik materyale zarar vermeye başlarlar². İskemi ve takip eden reperfüzyon, redoks dengesini prooksidanlar yönünde bozduğu gibi endotelyal aktivasyon aracılı̆̆ıyla inflamasyonu da tetiklemektedir ${ }^{3}$. Dolayısıyla iskemik hasar, oksidatif stresin başlattığı; ancak bilhassa reperfüzyon safhasında inflamasyonun dahil olduğu yıkıcı patolojik sürece işaret etmektedir. İskemik dokuda reperfüzyonun sağlanması sonrasında, umulanın aksine, hasarın şiddetleniyor olması "oksijen paradoksu" olarak bilinir ${ }^{4}$.
Antioksidanlar, söz konusu paradoksal hasara prooksidanların miktarını sınırlayarak karşı koyarlar ve böylece doku canlılığının sürdürülmesine yardımcı olurlar ${ }^{4}$. Antioksidan fitokimyasallar arasında flavonoid, tannin ve kateşinlerin önemli yer tuttuğu polifenol ailesinin yanı sıra geleneksel tıpta antihiperlipidemik, antihiperglisemik ve antikoagülan etkilerinden istifade edilen; ancak günümüzde antioksidan aktivitelerinin de farkına varılmış olan saponinler yer almaktadır ${ }^{5-7}$.

Türkiye'nin de aralarında bulunduğu Akdeniz iklimi ve subtropik iklime sahip bölgelerde yaygın şekilde yetişen Tribulusterrestris L. (demir dikeni) polifenol ve saponin açısından zengin içeriğiyle dikkat çekmektedir ${ }^{8,9}$. Başlıca polifenollerikuersetin, kampferol ve isorhamnetin iken aktif saponinlerispirostanol ve furostanolsaponinlerinden oluşur ${ }^{10-12}$. Tribulus; Anadolu, Mezopotamya, Çin ve Hindistan'da kardiyoprotektif, afrodizyak, 
antiinflamatuar gibi amaçlarla kullanım bulmaktadır8,13,14. Bilinen en eski (İ.Ö. 200 dolayları) Çin farmakopesi olan "ShenNong Ben CaoJing"deTribulus için "kötü kanı tedavi eder; sertlikleri, yapışıklıkları ve birikimleri çözer; boğaz tıkanıklığını tedavi eder; kas büyümesini teşvik eder" ifadelerine yer verilmiştir ${ }^{15}$. Bahsedilen ampirik bilginin en azından bir kısmı modern bilimsel raporlar tarafından desteklenir mahiyettedir. Misalen; Tribulus'un antioksidan aktivitesi sayesinde deneysel diyabet komplikasyonlarında histopatolojik iyileşmeye yol açtığ ${ }^{16}$, içeriğindeki saponin'ler yoluyla antifungal ${ }^{17}$ ve antibakteriyel ${ }^{18}$ karakter sergilediği, antihipertansif etkinliğe sahip olduğ ${ }^{19}$, salisilik asite üstün gelen analjezi sağladığ ${ }^{20}$ ortaya konulmuştur.

Mevcut çalışmada reperfüzyon hasarında oksidatif stresin yukarıda anılan rolü göz önünde bulundurularak, antioksidan özelliğe sahip polifenoller ve saponinler açısından zengin olduğu bilinen Tribulusterrestris L.'ninover, böbrek ve beyin dokularında iskemi sonrası reperfüzyonda redoks dengesine etkisi araştırılmıştır.

\section{YÖNTEMLER}

Hatay Mustafa Kemal Üniversitesi Deneysel Araştırmalar Uygulama ve Araştırma Merkezi'nde, standart laboratuvar koșulları altında $\left(22-24^{\circ} \mathrm{C}\right.$ sicaklık, 55\% rölatif nem, 12:12 saat aydınlık/karanlık döngüsü) tutulan erişkin, dişi Wistar albino sıçanlar $(\mathrm{N}=49$, 1416 hafta yaş, 300-350 g ağırlık) "Kontrol" grubuyla birlikte hasar bölgesine göre üçer alt gruba bölünen “İskemi/Reperfüzyon" (I/R) ve "Tribulus + İskemi/Reperfüzyon" (Tri.+I/R) ana gruplarına ayrıldı. Buna göre; Kontrol $(n=7)$ ve I/R ana gruplarındaki $(n=21)$ hayvanlara 5 gün boyunca oral gavaj yoluyla serum fizyolojik (1 ml) uyguland. Kontrol grubundaki hayvanlara müteakip günde 120 dakika süreli yalancı cerrahi (sham surgery) (horizontal faringotomi ve vertikal laparotomi) gerçekleştirilirken, I/R ana grubundaki hayvanlar Over $(n=7)$, Böbrek $(n=7)$ ve Beyin $(n=7)$ olmak üzere üç alt gruba ayrıldı. Over alt grubundaki hayvanların bilateral overyan arterlerine, Böbrek alt grubundaki hayvanların bilateral renal arterlerine ve Beyin alt grubundaki hayvanların bilateral ortak karotid arterlerine mikrovasküler klipsler yerleştirilerek 60 dakika süreli iskemi olușturuldu ve ardından klipsler uzaklaştırılarak 60 dakika süreyle reperfüzyona müsaade edildi. Tri.+I/R $(n=21)$ ana grubundaki hayvanlara ise 5 gün boyunca Tribulus terrestris L. ekstresi $(100 \mathrm{mg} / \mathrm{kg}$, p.o.,q.d.) uygulandıktan sonra hayvanlar Over $(n=7)$, Böbrek $(n=7)$ ve Beyin $(n=7)$ alt gruplarına ayrıldı ve ait oldukları gruba uygun şekilde I/R ana grubu için yukarıda ifade edilen işlemlere maruz bırakıldı. Cerrahi müdahaleler esnasında derin anestezi elde etmek için intraperitoneal ketamin/ksilazin kombinasyonu $(80 / 12 \mathrm{mg} / \mathrm{kg})$ kullanıldı. Tribulus ekstresi, ticari Tribestan $® 250 \mathrm{mg}$ film kaplı tabletlerin (Sopharma, Bulgaristan) toz halinde ezilmesi suretiyle elde edildi. Yalancı cerrahi veya reperfüzyon süresinin tamamlanmasını takiben eksanguinasyon yoluyla sakrifiye edilen hayvanların over, böbrek ve beyinleri eksize edildi ve dondurularak $\quad\left(\begin{array}{lll}-80 & { }^{\circ} \mathrm{C}\end{array}\right)$ analizler gerçekleştirilene kadar saklandı. Elde edilen dokularda ticari kitler (Rel Assay Kit Diagnostics, Türkiye) kullanılarak otoanalizör (Siemens Diagnostics, Erlangen, Almanya) marifetiyle total antioksidan seviye (TAS) ve total oksidan seviye (TOS) tayinleri yapıldı ve oksidatif stres indeksi [TOS mmol Trolokseq./lt /(TAS $\mu \mathrm{mol} \mathrm{H} 2 \mathrm{O} 2$ eq./lt x10)] hesaplandı. TAS tayininde kalibratör olarak troloks, TOS tayininde ise hidrojen peroksit kullanıldı. Kolmogorov-Smirnov testiyle verilerin parametrik olup olmadıkları araştırıldı ve parametrik olmadıkları görüldüğünden Graphpad Prism v7.0 (Kaliforniya, ABD) bilgisayar yazılımı yardımıyla Kruskal-Wallis ve post-hoc Dunn testleri ile istatistiksel analizleri gerçekleştirildi. Sonuçlar "ortanca ve çeyrekler 
arası aralık (\%25-75)" ş̧eklinde ifade edildi. İstatistiksel anlamlılık için $\mathrm{p}<0.05 \mathrm{kabul}$ edildi. Çalışma için Hatay Mustafa Kemal Üniversitesi Hayvan Deneyleri Yerel Etik Kurulu'ndan onay alınmıştır.
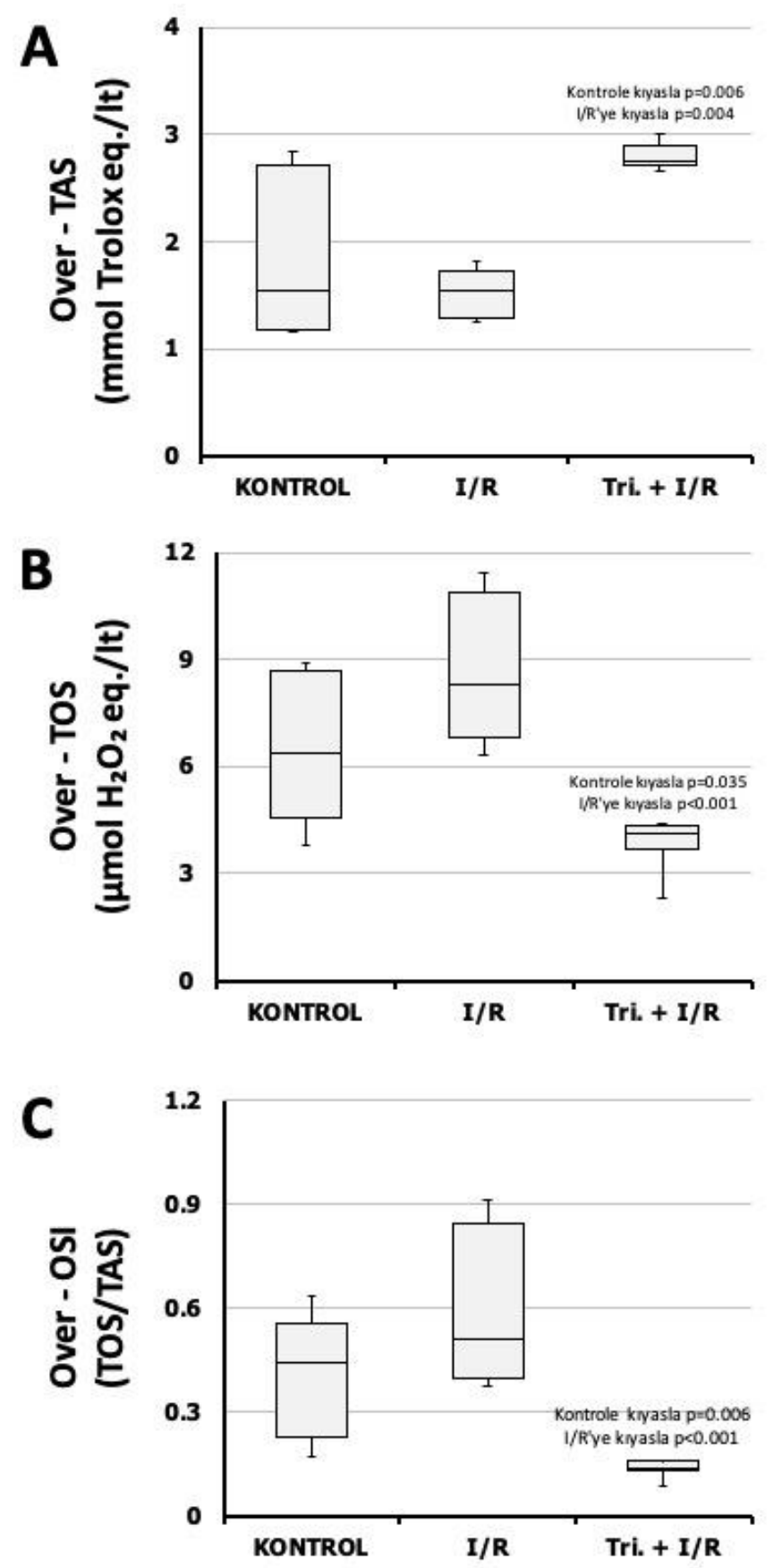

Şekil 1.Over dokusunda redoks parametreleri.

Şekil 1 alt açıklaması: Her parametre için gruplar arasında istatistiki anlamlılık (p<0.05) grafik çubuğu metni şeklinde gösterilmiştir. 

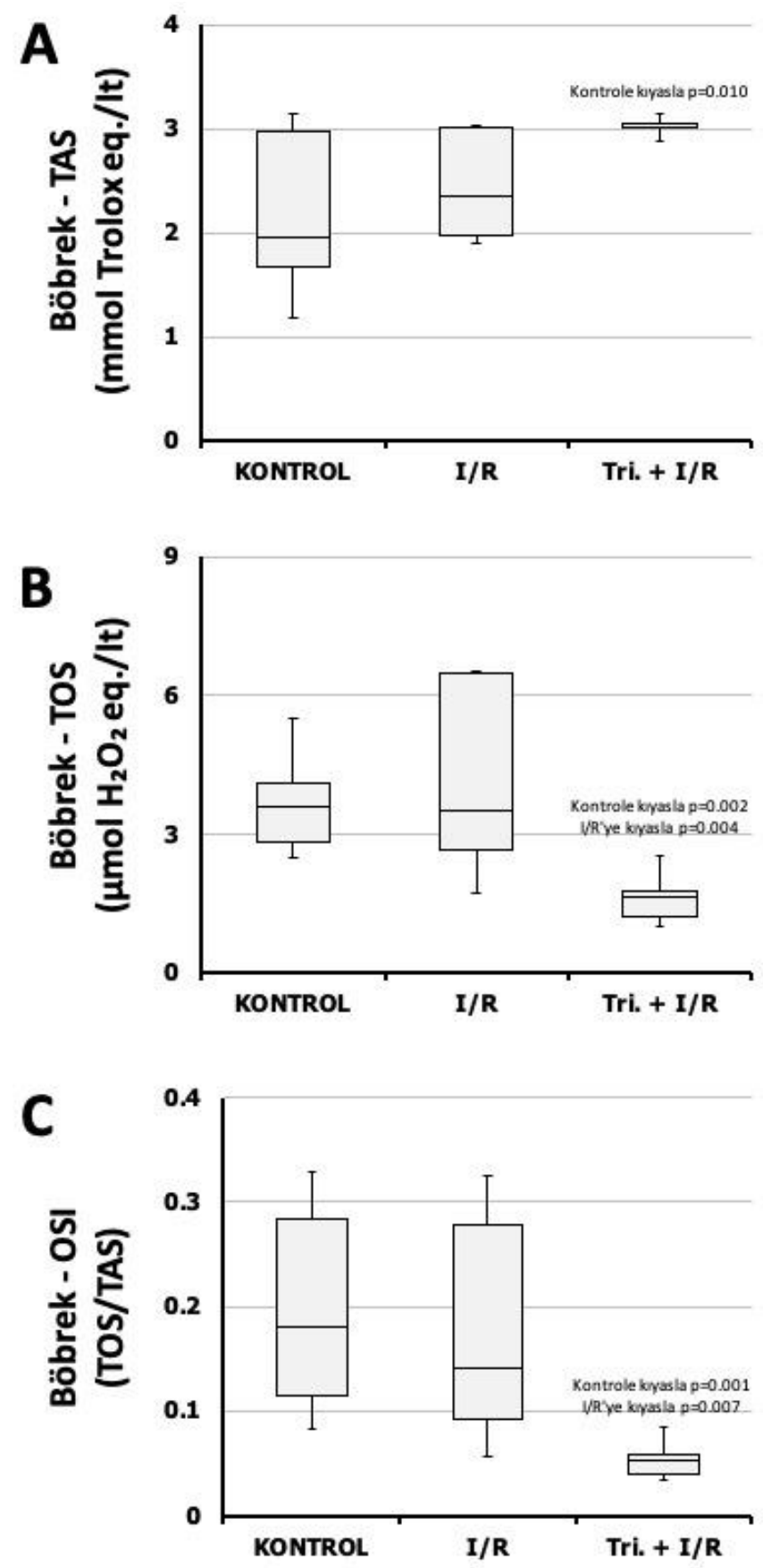

Şekil 2. Böbrek dokusunda redoks parametreleri.

Şekil 2 alt açıklaması: Her parametre için gruplar arasında istatistiki anlamlılık $(\mathrm{p}<0.05)$ grafik çubuğu metni şeklinde gösterilmiştir. 


\section{BULGULAR}

Over örneklerinde gruplar arasında her üç parametre açısından fark tespit edilmiş (TAS: $\mathrm{H}=10.56, \mathrm{p}=0.002$; TOS: $\mathrm{H}=12.92$, $\mathrm{p}<0.001$; OSI: $\mathrm{H}=14.03, \mathrm{p}<0.001$ ) ve farkın hangi gruplardan kaynaklandığını belirlemek üzere çoklu karşılaștırmaya başvurulmuştur. Şekil 1A'da resmedildiği üzere overdeiskemi/reperfüzyon sonrasında TAS'ın maksimal değerinde azalma gözlenmesine karşın Kontrol grubu ile istatistiksel farka rastlanmamıştır ( $\mathrm{p}=0.914)$. Buna mukabil Tribulus uygulanan hayvanlarda TAS, hem Kontrol hem I/R grubu örneklerine kıyasla anlamlı artış göstermiștir (sırasıyla $\mathrm{p}=0.006$ ve $\mathrm{p}=0.004$ ). Benzer şekilde TOS (Şekil 1B) açısından Kontrol ve I/R grupları arasında istatistiksel fark bulunmamakla birlikte $(p=0.143)$ iskemi/reperfüzyon sonrasında TOS'un minimal ve maksimal değerlerinde artış izlenmiştir. Tri.+I/R grubunda ise diğer gruplara kıyasla TOS'un azaldığı fark edilmiștir ( $p=0.035$ vs Kontrol, $p<0.001$ vs I/R). Şekil $1 C^{\prime}$ 'de gösterildiği gibi TOS'unTAS'a oranını ifade eden OSI açısından Kontrol ve I/R örnekleri arasında fark bulunmamıșken ( $p=0.413$ ) Tri.+I/R hayvanlarında OSI'nin diğer iki gruptan düşük olduğu gözlenmiştir ( $p=0.006$ vs Kontrol, $p<0.001$ vs $I / R$ ).

Böbrek örneklerinde TAS ( $\mathrm{H}=7.117, \mathrm{p}=0.022)$, TOS $(H=11.8, p=0.001)$ ve OSI $(H=12.04$, $\mathrm{p}=0.001$ ) açısından fark görülmüş ve buna istinaden farkın kaynağına dönük çoklu karşılaştırma gerçekleştirilmiştir. Renaliskemi / reperfüzyonun ardından TAS'ın Kontrol örneklerine klyasla fark arz etmediği $(\mathrm{p}=0.503) ;$ fakat Tribulus uygulanan hayvanlarda seviyelerinin arttığ görülmüștür ( $\mathrm{p}=0.010$ vs Kontrol) (Şekil 2A). TOS açısından Kontrol ve I/R grupları arasinda fark bulunmamasına $(\mathrm{p}=0.897)$ karşın Şekil 2B'de gösterildiği üzere Tri.+I/R örneklerinde TOS'un hem Kontrol $(p=0.002)$ hem I/R $(p=0.004)$ hayvanlarından düşük olduğu izlenmiştir. OSI, Tri.+I/R hayvanlarında diğer iki gruptan düşük $(\mathrm{p}=0.001$ vs Kontrol, $\mathrm{p}=0.007$ vs $\mathrm{I} / \mathrm{R})$ bulunmuşken Kontrol ve I/R örnekleri arasında farka rastlanmamıştır ( $\mathrm{p}=0.605)$ (Şekil 2C).

Beyin örneklerinde TAS ve TOS açısından eşik değere yakın olmakla birlikte anlamlı fark izlenmiş (sırasıyla $\mathrm{H}=6.112, \mathrm{p}=0.041$ ve $\mathrm{H}=6.909, \mathrm{p}=0.026$ ); ancak OSI açısından ise gruplar arasında farkın daha büyük olduğu görülmüştür $(\mathrm{H}=10.42, \quad \mathrm{p}=0.002)$. Farkların kaynağ hayvanlarında TAS'ın benzer olduğu $(\mathrm{p}=0.829)$; fakat iskemi/reperfüzyon sonrası Tribulus uygulanan hayvanlarda TAS'ın hem Kontrol hem I/R gruplarına göre artış sergilediği fark edilmiştir (sırasıyla $p=0.0251$ ve $p=0.043$ ) (Şekil 3A). TOS ise Kontrol ve Tri.+I/R gruplarında benzer bulunmakla birlikte $(p=0.763) \quad I / R$ hayvanlarında Kontrol ve Tri.+I/R örneklerine göre yüksek görülmüştür (sırasıyla $p=0.016$ ve $p=0.035$ ) (Şekil 3B). Şekil $3 C$ 'de ifade edildiği üzere Tri.+I/R grubunda OSI'nin hem Kontrol hem I/R hayvanlarından yüksek olduğu (sırasıyla $p=0.016$ ve $p=0.002$ ), diğer taraftan Kontrol ve I/R grupları arasında OSI açısından fark bulunmamasına karşın ( $p=0.464) \quad$ iskemi/reperfüzyon sonrasında OSI'nin minimal ve maksimal değerlerinde artış izlenmiştir.

\section{TARTIŞMA}

$\mathrm{Bu}$ çalışmada over, böbrek veya beyinde 60 dakika süreli iskemi sonrasında 60 dakika süreyle reperfüzyon gerçekleștirilmiş ve ilgili dokularda Tribulus terrestris L. ekstresinin total antioksidan seviye, total oksidan seviye ve oksidatif stres indeksi üzerine etkileri incelenmiştir.

İskemi/reperfüzyon sürecinde hasarında iskemik hasar ve reperfüzyon hasarı olmak üzere iki komponentten söz edilebilir ${ }^{21}$. İskemik hasarda temel sorun hücrenin enerji depolarının tükenmesi neticesinde iyon kanallarının çalışamaz hale gelmesi ve intrasellüler iyon dengesinin bozulmasiyken, reperfüzyon hasarında oksidatif/nitrosatif stres ve inflamasyon ön plana çıkmaktadır ${ }^{21,22}$. 
Reperfüzyon hasarının şiddeti iskemi süresiyle doğrudan ilişkilidir; ancak organ ve dokuların iskemiye duyarlılıkları farklılık gösterir ${ }^{22}$. Uzamış hasarın nihai sonucu hücre ölümü olacakken kısa süreli hasar, hücresel sağ kalım mekanizmasının aktivasyonuyla birlikte reaktif oksijen türevlerinin üretimine ve hücresel hasara yol açar21. Mevcut çalıșma reperfüzyon hasarında hücresel ölüm ya da să̆ kalım süreçlerinin histopatolojik veya biyokimyasal yönlerinden ziyade hasara bağlı redoks dengesi değişimlerine ve bu değişimler noktasında Tribulus'un etkilerine odaklanmıștır.
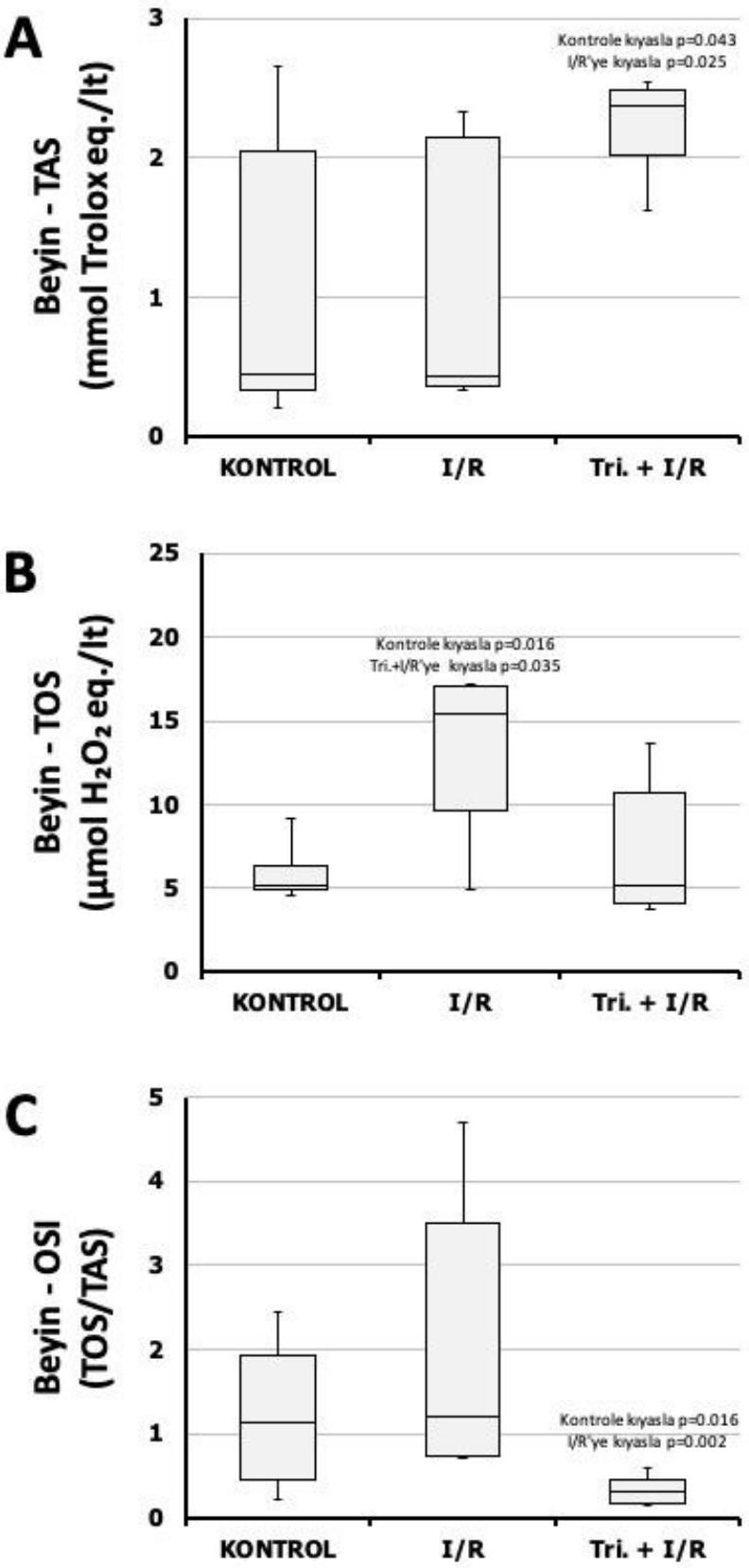

Şekil 3. Beyin dokusunda redoks parametreleri.

Şekil 3 alt açıklaması: Her parametre için gruplar arasında istatistiki anlamlılık $(\mathrm{p}<0.05)$ grafik çubuğu metni şeklinde gösterilmiştir. 
İncelenen over, böbrek ve beyin dokularında yalnızca reperfüzyon hasarı oluşturulan hayvanlarla kontrol örnekleri arasında total antioksidan seviye açısından farka rastlanmamıştır. Yukarıda ifade edildiği üzere bu sonuç reperfüzyon hasarının şiddetini değil, hasar neticesinde endojen antioksidan aktivitenin düzeyini göstermektedir. Bununla birlikte total oksidan seviye, iskemik hasara en duyarlı organ olan beyinde ${ }^{23}$ kontrol örneklerine klyasla yüksek bulunmuş, over ve böbrekte ise fark izlenmemiştir. Prooksidanlardaki artışa yanıt, antioksidanların artışı yönündedir ${ }^{24}$. Dolayısıyla redoks dengesinin durumunu; yani antioksidanların prooksidanlara hangi düzeyde karşılık verebildiğini değerlendirmek açısından oksidatif stres indeksi, total antioksidan ve total oksidan seviyeye nazaran daha güvenilir bir belirteçtir ${ }^{25}$. Bu çalışmada her ne kadar reperfüzyon hasarı sonrasında oksidatif stres indeksinin maksimal değerlerinde artış izlenmişse de gelişen fark istatistiki anlamlılık düzeyine ulaşmamıștır. Buradan hareketle iskemi ve/veya reperfüzyon süresinin redoks dengesini bozmaya yetmediği sonucuna varılmaktadır. Diğer taraftan çalışmanın odağını teşkil eden Tribulus uygulamasının araștırılan her üç dokuda reperfüzyon hasarı sonrasinda total antioksidan seviyeyi arttırırken total oksidan seviyeyi düşürdüğü ve redoks dengesi açısından önemi vurgulanan oksidatif stres indeksinde azalmaya yol açtığı görülmüştür. Çarpıcı şekilde, Tribulus uygulanan hayvanlarda reperfüzyon hasarına rağmen oksidatif stres indeksi, reperfüzyon hasarı oluşturulmayan kontrol örneklerinden daha düşük izlenmiştir. Bu bulgu Tribulus'un genel olarak güçlü bir radikal temizleyici ${ }^{26,27}$ olduğuna dair raporları desteklemekte ve redoks dengesinin korunmasina katkı sunabileceğini göstermektedir. Buna karşın Tribulus'un mevcut çalışmada incelenen böbrek dokusunda reperfüzyon hasarında redoks dengesinin korunması açısından etkinliğine dair rapolar oldukça sınırlıdır. Tıbbi literatürdeki nadir çalışmalardan birinde Najafi ve ark. ${ }^{28}$, Tribulus uygulamasının 30 dakika renaliskemiyi takip eden 24 saat süreli reperfüzyon sonrasinda oksidatif stresi azalttığını ortaya koymuştur. Tribulus ekstresinin over ve beyinde reperfüzyon hasarında redoks dengesine etkisine dair geçmiş çalışmaya ise rastlanamamıştır. Diğer taraftan Tribulus'un zengin şekilde barındırdığ flavonoid'ler ve saponin'lerin bu dokularda redoks dengesinin korunmasina katkl sunabileceği bilinmektedir ${ }^{29,30}$.

Reperfüzyon hasarı, fizyopatogenezinde oksidatif stresin önemli yer işgal ettiği yıkıcı bir süreçtir. Mevcut çalışma Tribulus terrestris L. ekstresinin over, böbrek ve beyinde reperfüzyon hasarı sonrasında redoks dengesinin korunmasında potansiyel faydasını ortaya koymuştur.

\section{TEŞEKKÜR}

Destekleri için C. Tümer, H. Doğan, O. Tutuk ve A. Arpacı'ya teșekkür ederiz.

Çıkar Çatışması: Yazar bu yazının hazırlanması ve yayınlanması hususunda çıkar çatışması olmadığını beyan etmiştir.

Finansal Destek: Çalışmamız, herhangi bir fondan maddi destek almamıştır.

Declaration of Conflicting Interests: The authors hereby declare that they have no conflict of interest.

Financial Disclosure: No financial support was received. 


\section{KAYNAKLAR}

1. Czerska M, Mikołajewska K, Zieliński M, et all. Today's oxidative stress markers. Med Pr. 2015; 66: 393-405.

2. Rajendran P, Nandakumar N, Rengarajan T, et all. Antioxidants and human diseases. Clin Chim Acta. 2014; 436: 332-47.

3. Cuzzocrea S, Riley DP, Caputi AP, et all. Antioxidant therapy: a new pharmacological approach in shock, inflammation, and ischemia/reperfusion injury. Pharmacol Rev. 2001; 53: 135-59.

4. Zweier J, Talukder M. The role of oxidants and free radicals in reperfusion injury. Cardiovasc Res. 2006; 70: 181-90.

5. Zhang Y-J, Gan R-Y, Li S, et all. Antioxidant Phytochemicals for the Prevention and Treatment of Chronic Diseases. Molecules. 2015; 20: 21138-56.

6. Sun A, Xu X, Lin J, et all. Neuroprotection by Saponins. Phyther Res. 2015; 29: 187-200.

7. Singh B, Singh JP, Singh N, et all. Saponins in pulses and their health promoting activities: $\mathrm{A}$ review. Food Chem. 2017; 233: 540-9.

8. Adaikan P, Gauthaman K, Prasad R. History of herbal medicines with an insight on the pharmacological properties of Tribulus terrestris. Aging Male. 2001; 4: 163-9.

9. Chhatre S, Nesari T, Somani G, et all. Phytopharmacological overview of Tribulus terrestris. Pharmacogn Rev. 2014; 8: 45-51.

10. Mashchenko NE, Gyulemetova R, Kintya PK, et all. A sulfated glycoside from the preparation "tribestan." Chem Nat Compd. 1990; 26: 552-5.
11. Kostova I, Dinchev D. Saponins in Tribulus terrestris-chemistry and bioactivity. Phytochem Rev. 2005; 4: 111-37.

12. Zhu W, Du Y, Meng H, et all. A review of traditional pharmacological uses, phytochemistry, and pharmacological activities of Tribulus terrestris. Chem Cent J. 2017; 11: 60.

13. Park YJ, Cho Y-R, Oh JS, et all. Effects of Tribulus terrestris on monosodium iodoacetate-induced osteoarthritis pain in rats. Mol Med Rep. 2017; 16: 5303-11.

14. Polat R. Ethnobotanical study on medicinal plants in Bingöl (City center) (Turkey). J Herb Med. 2018; 100211.

15. Yang S. The divine farmer's materia medica: a translation of the Shen Nong Ben Cao Jing, 5th edn. Boulder, CO: Blue Poppy Press, 2007: 1-43.

16. Amin A, Lotfy M, Shafiullah M, et all. The Protective Effect of Tribulus terrestris in Diabetes. Ann N Y Acad Sci. 2006; 1084: 391401.

17. Zhang J-D, Xu Z, Cao Y-B, et all. Antifungal activities and action mechanisms of compounds from Tribulus terrestris L. J Ethnopharmacol. 2006; 103: 76-84.

18. Usman $\mathrm{H}$, Abdulrahman $\mathrm{F}$, Ladan A. Phytochemical and Antimicrobial Evaluation of Tribulus terrestris L. (Zygophyllaceae) Growing in Nigeria. Res J Biol Sci. 2007; 2: 244-7.

19. Phillips OA, Mathew KT, Oriowo MA. Antihypertensive and vasodilator effects of methanolic and aqueous extracts of Tribulus terrestris in rats. J Ethnopharmacol. 2006; 104: 351-5. 
20. Heidari MR, Mehrabani M, Pardakhty A, et all. The analgesic effect of Tribulus terrestris extract and comparison of gastric ulcerogenicity of the extract with indomethacine in animal experiments. Ann N Y Acad Sci. 2007; 1095: 418-27.

21. Wu M-Y, Yiang G-T, Liao W-T, et all. Current Mechanistic Concepts in Ischemia and Reperfusion Injury. Cell Physiol Biochem. 2018; 46: 1650-67.

22. Kalogeris $\mathrm{T}$, Baines $\mathrm{CP}, \mathrm{Krenz} \mathrm{M}$, et all. Ischemia/Reperfusion. Compr Physiol. 2016; 7: 113-70.

23. Kalogeris T, Baines CP, Krenz M, et all. Cell biology of ischemia/reperfusion injury. Int Rev Cell Mol Biol. 2012; 298: 229-317.

24. Comhair SAA, Erzurum SC. Antioxidant responses to oxidant-mediated lung diseases. Am J Physiol Cell Mol Physiol. 2002; 283: L246-55.

25. Abuelo A, Hernández J, Benedito JL, et all. Oxidative stress index (OSi) as a new tool to assess redox status in dairy cattle during the transition period. Animal. 2013; 7: 1374-8.
26. Zheleva-Dimitrova D, Obreshkova D, Nedialkov P. Antioxidant activity of Tribulus terrestris-a natural product in infertility therapy. Int J Pharm Pharm Sci. 2012; 4: 50811.

27. Zhang S, Li H, Yang S. Tribulosin protects rat hearts from ischemia/reperfusion injury. Acta Pharmacol Sin. 2010; 31: 671-8.

28. Najafi H, Firouzifar MR, Omid S, et all. Protective Effects of Tribulus Terrestris L Extract Against Acute Kidney Injury Induced By Reperfusion Injury in Rats. Iran J Kidney Dis. 2014; 8: 292-8.

29. Melekoglu R, Ciftci O, Eraslan S, et all. The Protective Effects of Glycyrrhetinic Acid and Chrysin against Ischemia-Reperfusion Injury in Rat Ovaries. Biomed Res Int. 2018; 2018: 5421308.

30. Nayki C, Nayki U, Keskin Cimen F, et all. The effect of rutin on ovarian ischemiareperfusion injury in a rat model. Gynecol Endocrinol. 2018; 34: 809-14. 